dexamethasone and induction of tyrosine aminotransferase in neonatal rat liver. Biochem. Biophys. Res. Commun. 54: 983 (1973).

7. Chambon, P.: Eukariotic nuclear RNA polymerase:Ann. Rev. Biochem., 44: 613 (1975).

8. Drews, J., and Wagner, L.: The effect of prednisolone injected in vivo on RNA polymerase activities in isolated rat thymus nuclei. Eur. J. Biochem., 13: 231 (1970).

9. Eurenius, K., Dalton, T. V., Lokey, H. J., and McIntyre, O. R.: The mechanism of glucocorticoid action on the PHA-stimulated lymphocyte. Biochim. Biophys. Acta, 177: 572 (1969).

10. Hofert, J. F., and White, A.: Effect of a single injection of cortisol, administered in vivo, on the in vitro incorporation of DNA and RNA precursors by rat thymus cells. Mol. Pharmacol., 3: 219 (1967).

11. Kirkpatrick, A. F., Kaiser, N., Milholland, R. J., and Rosen, F.: Glucocorticoid-binding macromolecules in normal tissues and tumors. J. Biol. Chem., 247: 70, (1972).

12. Lipp, K., van der Meulen, N., and Linneweh, F.: Dexamethason-bindung von Lymphocyten aus Blut und Milz und von Thymocyten. Pädiat. Pädol. (In press.)

13. Litwack, G., Filler, R., Rosenfeld, S. A., Lichtash, N., Wishman, A. C., and Singer, S.: Liver cytosol corticosteroid binder II, a hormone receptor. J. Biol. Chem., 193: 265 (1973).

14. Lowry, O. H., Rosebrough, N. J., Farr, A. L., and Randall, R. J.: Protein measurement with Folin phenol reagent. J. Biol. Chem., 193: 265 (1951).

15. Makman, M. W., Dvorkin, B., and White, A.: Alteration in protein and nucleic acid metabolism of thymocytes produced by adrenal steroids in vitro. J. Biol. Chem., 241: 1646 (1966).

16. McAnulty, P. A., and Dickerson, J. W. T.: The cellular response of the weanling rat thymus gland to undernutrition and rehabilitation. Pediat. Res., 9: 778 (1973).

17. van der Meulen, N., Abraham, A. D., and Sekeris, C. E.: Role of the nuclear cortisol binding protein in the control of transcription of thymocyte nuclei by cortisol. FEBS Lett., 25: 116 (1972).

18. van der Meulen, N., Lipp, K., and Sekeris, C. E.: Postnatale Adaptation und ihre hormonelle Kontrolle. Klin. Wschr., 52: 571 (1974).

19. Roth, G. S.: Age-related changes in glucocorticoid binding by rat splenic leukocytes: Possible cause of altered adaptive responsiveness. Fed. Proc. 34: 183 (1975).

20. Schaumburg, B. P.: Studies of the glucocorticoid-binding protein from thymocytes. I. Localization in the cell and some properties of the protein. Biochim. Biophys. Acta, 214: 520 (1970).

21. Seifart, K. H., and Benecke, B. J.: DNA-dependent RNA polymerase C: Occurrence and localization in various animal cells. Eur. J. Biochem., 53: 293 (1975)

22. Smythe, P. M., Schonland, M., Brereton-Stiles, G. G., Coovadia, H. M. Grace, H. J., Loening, W. E. K., Mafoyane, A., Parent, M. A., and Vos, G. H.: Thymolymphatic deficiency and depression of cell-mediated immunity in protein-calorie malnutrition. Lancet, ii: 939 (1971).

23. Werthamer, S., Samuels, A. J., and Amaral, L.: Identification and partial purification of transcortin-like protein within human lymphocytes. J. Biol. Chem., 248: 6398 (1973).

24. Wira, C., and Munck, A.: Specific glucocorticoid receptors in thymus cells. J. Biol. Chem., 245: 3436 (1970).

25. Whitfield, J. F., Perris, A. D., and Yondale, T.: Destruction of nuclear morphology of thymic lymphocytes by the corticosteroid cortisol. Exp. Cell Res., 52: 349 (1968).

26. Hanover, Germany.

27. Amersham, England.

28. Grand Island, N.Y.

29. Uppsala, Sweden.

30. Maidstone, England.

31. Heidelberg, Germany.

32. Karlsruhe, Germany.

33. Darmstadt, Germany.

34. Mannheim, Germany.

35. The authors gratefully acknowledge the skilled technical assistance of Miss R. Stössel and Mrs. G. Wenske.

36. This research was supported by the Deutsche Forschungsgemeinschaft.

37. Requests for reprints should be addressed to: K. Lipp, M.D., UniversitätsKinderklinik, Humboldtallee 38, 34 Göttingen (West Germany).

38. Received for publication July 18,1976

39. Accepted for publication October 8, 1976.

\title{
Rapid Eye Movement Sleep, Motoneurone Inhibition, and Apneic Spells in Preterm Infants
}

\author{
FRANZ J. SCHULTE, ${ }^{28}$ CORD BUSSE, AND WALTRAUD EICHHORN \\ Department of Pediatrics II, University of Göttingen, West Germany
}

\section{Summary}

Not principally different from the results obtained in more mature subjects, monosynaptic reflex excitability of spinal motoneurones in preterm infants decreases during active sleep. However, in preterm infants the electric reflex response is not abolished, and is not even continuously depressed during the entire active sleep period. Spinal motoneurone inhibition is demonstrable only during certain periods of active sleep, and it is during this state of decreased spinal motoneurone excitability when apneic spells predominantly occur.

\section{Speculation}

The concept of apneic spells being promoted by rapid eye movement (REM) sleep brain mechanisms, as outlined by Gabriel et al. (10) and supported by data of this study, can so far mainly explain respiratory pauses in otherwise healthy preterm infants. However, in neonatal sepsis, meningitis, hypoxia, hypo- glycemia, etc., the same central nervous system inhibitory processes should increase the risk of apneic spells, provided that active sleep states still exist. Furthermore, Bryan and Bryan (2) have demonstrated a considerable thoracic wall instability during active sleep, which is probably also due to inhibition of spinal motoneurones innervating intercostal muscles. Thus, when respiratory brain stem centers are partly damaged, tonic spinal motoneurone inhibition during active sleep can additionally increase the infant's difficulty in maintaining sufficient respiration.

"REMS is a time of profound motor paralysis in which tendon reflexes cannot be elicited and in which voluntary movement is impossible" (W. Dement, 1972 (4))-otherwise our dreams would have serious consequences.

There is increasing evidence in the literature that in infants short respiratory pauses $(25)$ and periodic breathing $(8,20)$, as well as apneic spells with and without bradycardia $(9-11,17)$ 
occur predominantly in active or REM sleep. For our understanding of the neurophysiologic events leading to respiratory arrest in preterm infants during active sleep, inhibitory mechanisms influencing spinal motoneurones, including respiratory neurones, are of great importance. It is well known from experimental studies in animals $(1,12,13,16)$, in human infants and adults $(14,15)$, and in full term newborns (23) that during REM sleep spinal motoneurones are subject to strong descending inhibitory influences. However, in immature infants the level of organization of sleep states, i.e., the development and coordination of the different brain mechanisms which comprise active or quiet sleep, are still poor $(5,6)$. It is therefore, the subject of this study to clarify whether in preterm infants spinal motoneurone inhibition occurs at all during active sleep, whether it is maintained during the whole period of long lasting immature REM states, and whether this inhibition increases in relation to apneic spells.

\section{SUBJECTS (TABLE 1)}

Seven preterm infants with a gestational age of 30-37 weeks (birth weight normal for age) were investigated at a conceptional age (gestational age plus age from birth) of 30.5-38 weeks. In five infants a second polygraphic recording was obtained after 35 weeks. Infants were included in this study only when their mothers were certain about their last menses and when pregnancy, birth, and postnatal period were uneventful except for premature delivery. Only one infant had recurrent and pronounced apnea which required intensive care monitoring but not artificial respiration. Neurologic and physical examinations in the postnatal period and at the time of discharge were normal and appropriate for conceptional age.

\section{RECORDING TECHNIQUE}

Twelve polygraphic sleep recordings $1-2 \mathrm{hr}$ in duration were obtained with at least one complete sleep cycle (one active and one quiet sleep state) being monitored. During the recording the infants were kept under normal incubator conditions at neutral temperature and room air. Polygraphic recordings were done on an 8-channel Schwartzer EEG machine and consisted of (1) respiration, registered by a thermistor attached to the infant's nose and, additionally, by expiratory $\mathrm{CO}_{2}$ estimation via a tube in the epipharyngeal space; (2) heart rate, recorded by conventional electrocardiogram; (3) facial and body activity, continuously observed during the recording and indicated by a code on the paper write-out; $(4)$ observed rapid eye movements, registered by a pushbutton device; (5) EEG, recorded with silversilver chloride stick-on electrodes in a montage of four bipolar leads from bilateral frontocentral and frontotemporal regions. The electrode resistance was about 4-5 kilo-ohms, the time constant $0.3 \mathrm{sec}$ with a high frequency filter at $70 \mathrm{cps}$. Every 5-6 min four to seven gastrocnemius monosynaptic stretch reflexes (MSR) were elicited by constant tendon taps with a conventional reflex hammer. The intervals between two reflexes were about 1 sec each. The electric reflex responses were recorded with EMG skin electrodes and registered on a Toennies-Siemens EMG machine.

\section{ANALYSIS OF POLYGRAMS}

All records were visually analyzed page by page (20-sec epochs). Respiration was coded as regular, irregular, or periodic. Pauses of more than 10-sec duration were coded as apnea. Most of the apneic spells ceased spontaneously, a few were terminated by manual stimulation only. Heart rate was counted from the electrocardiogram. EEG patterns were coded according to our coding system which has been extensively described previously $(18,23)$. With this coding system we are able to recognize special EEG patterns indicative of active and others of quiet sleep at different conceptional age levels. The amplitude of the electric reflex responses was measured and indicated in microvolts.

\section{DEFINITION OF SLEEP STATES}

Three subsequent minutes were combined for the identification of sleep states which were defined as follows: quiet or nonREM sleep, paroxystic EEG with long lasting bioelectric blackouts without any rapid eye movements and regular respiration; active or REM sleep, nonparoxystic although frequently discontinuous EEG with rapid eye movements and/or body movements and irregular respiration. Every 3-min sleep period which could not be identified as either active or quiet sleep was classified as undifferentiated sleep.

\section{FALLACIES OF METHOD}

The definition of sleep states can be rather difficult in very immature preterm infants. Rapid eye movements under closed lids can sometimes be missed, small body movements do occur in both sleep states, and respiration can be irregular for short periods even in quiet or non-REM sleep. We therefore combined $3 \mathrm{~min}$ for identification of sleep states, thus neglecting short interruptions of an on-going sleep cycle if their duration was only $2 \mathrm{~min}$ or less. The distribution of sleep states found in this study is in accordance with what is reported in the literature (18). Thus, the introduction of monosynaptic stretch reflexes into the polygraphic recording did not substantially change the duration, the maintainance, and distribution of sleep states in preterm infants.

The amplitude of the electric reflex response certainly varies not only with sleep states but also with the level of excitation of the spinal motoneuron pool which depends, among other variables, upon the force of the tendon tap. The examiner, therefore, was not allowed to follow the polygraphic recording. However, rough identification of the behavioral state just by watching the baby could not be avoided. With the conventional reflex hammer, however, the reflex stimulus in preterm infants usually turned out to be supramaximal and this at least partly eliminated one important source of error.

The great interindividual differences of the mean reflex amplitude was found to be mainly due to electrode placement and perhaps partly due to gastrocnemius muscle mass. This difference, however, is not a source of error, since in every case of reflex depression it was ascertained that the reflex response had completely recovered.

Table 1. Seven infants were investigated; in five infants two polygraphic recordings were obtained at different conceptional ages (gestational age plus age from birth)

\begin{tabular}{lccccc}
\hline Case & Initials & Chart no. & $\begin{array}{c}\text { Gestational age, } \\
\text { weeks/days }\end{array}$ & Clinical course & $\begin{array}{c}\text { Conceptional age at record- } \\
\text { ing, weeks/days }\end{array}$ \\
\hline 1,4 & $R W$ & 81189 & $30 / 0$ & Uneventful & $30 / 3$ \\
2,10 & $O L$ & 81018 & $32 / 0$ & Uneventful & $33 / 4$ \\
3,9 & $M T$ & 81025 & $28 / 5$ & Unevientful & $32 / 4$ \\
5,8 & $S B$ & 80903 & $28 / 3$ & Pronounced apnea & $32 / 4$ \\
6 & $K K$ & 81584 & $33 / 3$ & Uneventful & $36 / 6$ \\
7,11 & $C T$ & 80905 & $28 / 6$ & Uneventful & $33 / 6$ \\
12 & $R L$ & 81323 & $36 / 6$ & Uneventful & $34 / 0$ \\
\hline
\end{tabular}


Table 2. Duration of sleep states, number of tendon taps, and incidence of apneic spells for each single recording ${ }^{1}$

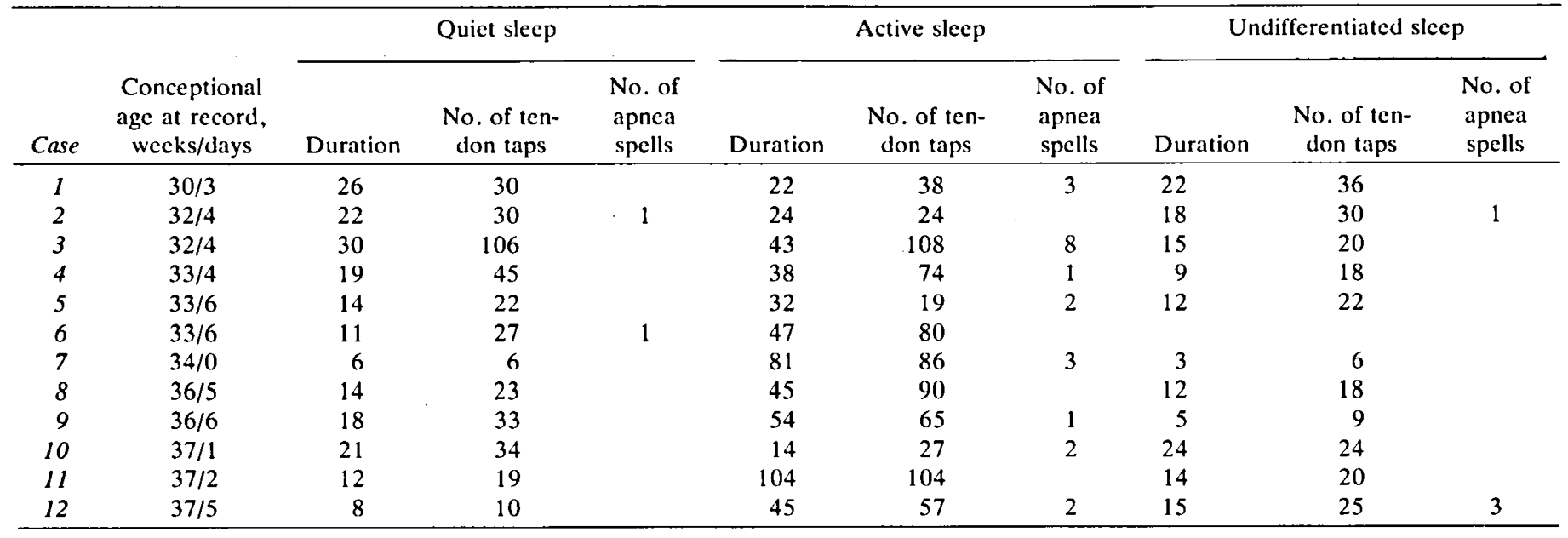

' Even in the most immature infants, quiet sleep states were long enough to elicit a sufficient number of tendon taps.

\section{RESULTS}

Table 2 is a summary of the raw data of every recording made, indicating conceptional age of the infant at the time of investigation, the duration of the different sleep states, the total number of tendon taps, and the occurrence of apnea in each sleep state.

During well defined quiet or non-REM sleep the amplitude of the gastrocnemius monosynaptic stretch reflex response is significantly higher than during REM or active sleep (Fig. 1). During the whole series we were able to elicit multiple (i.e., clonic reflex) responses, which indicate high motoneurone excitability, only three times, and in all three cases these occurred during quiet sleep (Fig. 2). During active sleep, however, the MSR was not completely abolished. The amplitude of the electric responses varied a little more during active than during quiet sleep, in 9 out of 12 recordings the first standard deviation was greater in active than in quiet sleep (Fig. 3 ). It could be noticed in all of our recordings that every now and then, particularly towards the end of the active sleep state, the reflex response increased, whereas it was depressed mainly during the first minutes after the sleep state had changed from quiet to active (this is apparent in Fig. 4).

Apneic spells occurred more frequently during active than during quiet sleep even if one corrects for the greater amount of time the infants spend in active sleep (Table 3 ). So far, this study confirms the results obtained earlier in our laboratory on a different group of infants $(9,10)$. In this series it so happened that seven apneic spells occurred just when tendon taps were being applied. In all seven cases the amplitude of the reflex responses decreased during the apnea, when compared with the previous reflex series, regardless whether the baby was in active or quiet sleep (Fig. 5).

\section{DISCUSSION}

Not principally different from the results obtained in more mature subjects, monosynaptic reflex excitability of spinal motoneurones decreases in preterm infants during active sleep. However, in preterm babies the electric reflex response is not abolished, or even continuously depressed during the entire active sleep period. In contrast to similar studies, particularly with tendon reflexes in adults (12), but quite in agreement with similar investigations in full term infants (23), our results indicate that during active sleep in preterm babies, periods of strong spinal motoneurone inhibition alternate with those of no detectable inhibition at all.

It is worthwhile to mention that Eliet-Fletcher and DreyfusBrisac (7) found tonic activity in chin muscle during quiet sleep likewise more inconsistent in preterm infants. Thus, in the early

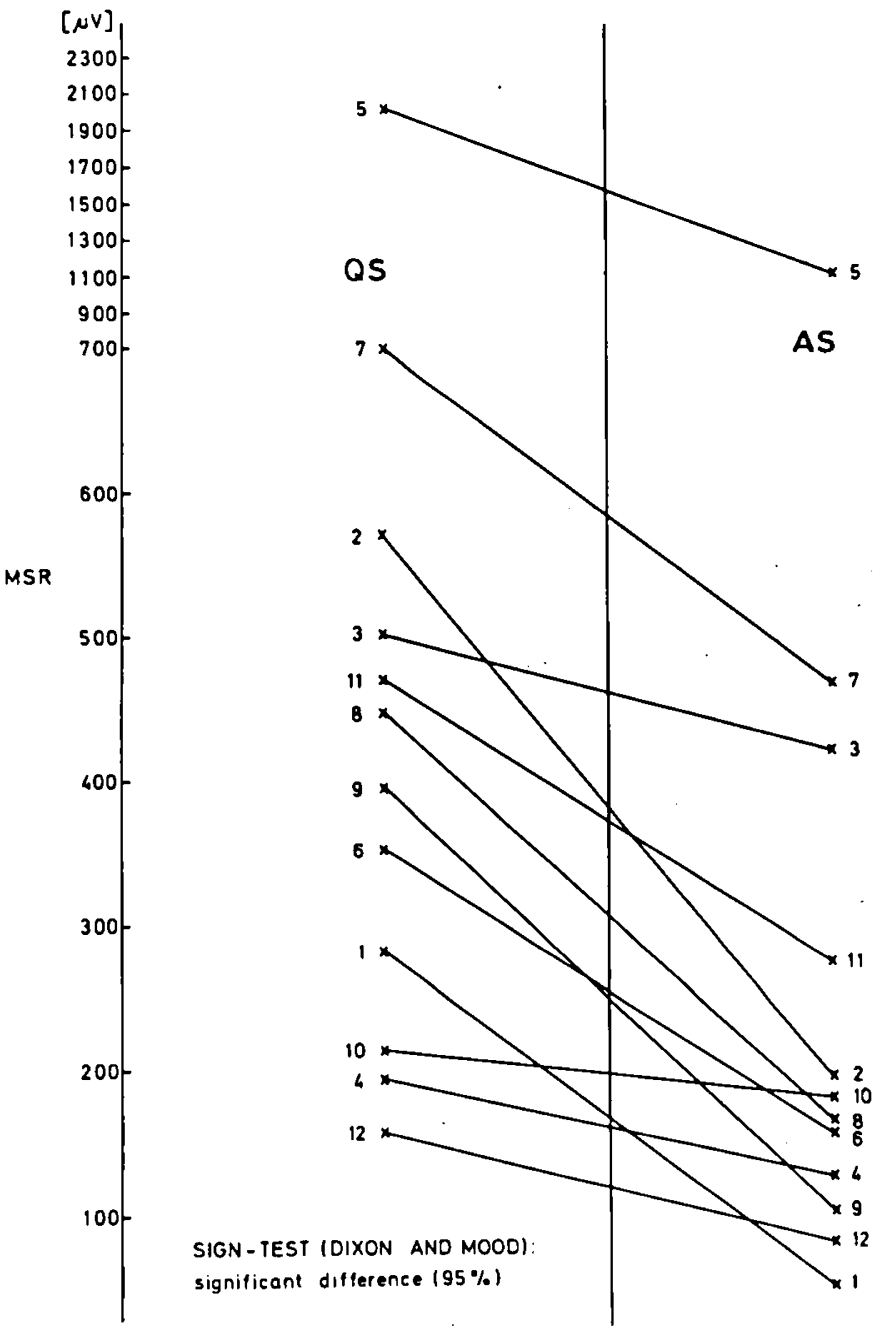

Fig. 1. The mean amplitude of all monosynaptic stretch reflexes (MSR) elicited by tendon taps and electrically recorded from gastrocnemius muscle was higher in quiet sleep $(Q S)$ than in active sleep $(A S)$ in all 12 recordings.

stages of central nervous system development the tonically sustained processes of sleep state behavior, like motoneurone inhibition in active sleep and antigravity muscle tone in quiet sleep, show considerable inconsistency. 
No: $80903 \quad 36 / 5$ whs conc. age

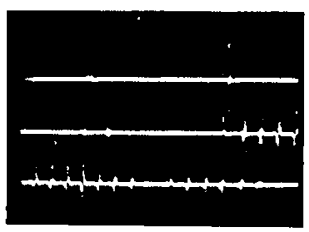

No: $8118933 / 4$ wks conc. age



No: $8118933 / 6$ wks cone. age

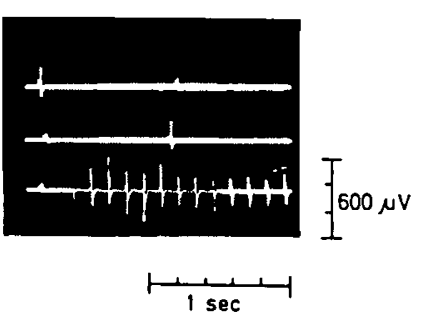

Fig. 2. During 12 polygraphic records $1-2 \mathrm{hr}$ in duration and a total of over 1,000 tendon taps we were able to elicit multiple (i.e., clonic) reflex responses, indicative of high motoneurone excitability, only three times. All three cases are depicted in this figure. Lefi: three consecutive lines each of three continuous EMG recordings with myoclonic discharges. Right: mean amplitude $(\bar{x})$ of cloni and first standard deviation $(S)$. All three cases occurred during quiet sleep.

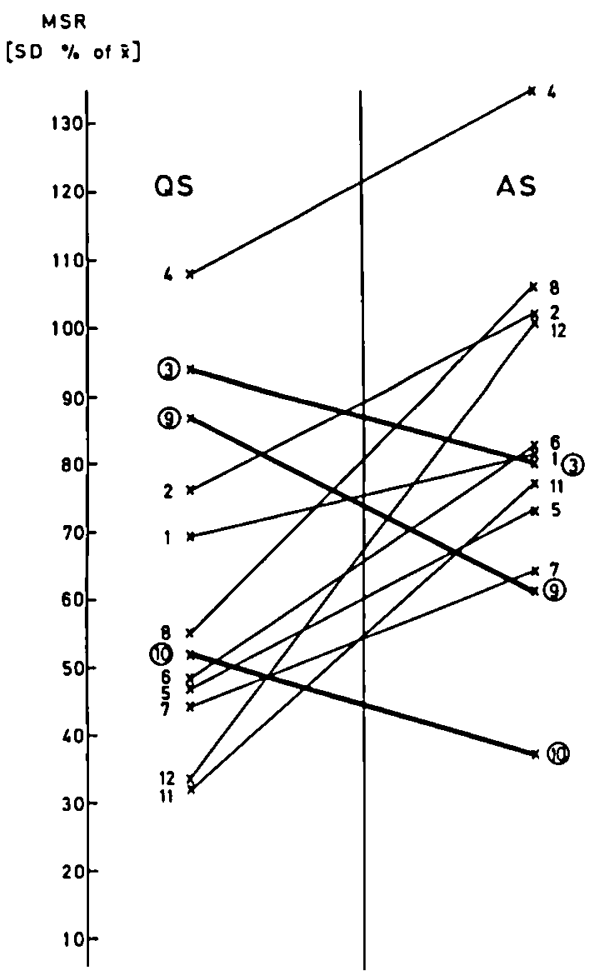

Fig. 3. The amplitude of monosynaptic stretch reflexes $(M S R)$ varied during both active sleep $(A S)$ and quiet sleep (QS). Except for three recordings, the variance was greater in active than in quiet sleep.
Nevertheless, also in preterm infants spinal motoneurone inhibition is demonstrable during active sleep and it is during this state of behavior that apneic spells predominantly occur. During apneic spells the reflex responses are particularly depressed, indicating increased spinal motoneurone inhibition. From a detailed analysis of our results it seems unlikely that reflex depression is due to apneic hypoxia. Some of the apneic spells are much too short to cause hypoxic motoneurone depression at all. Moreover, motoneurone inhibition occurs at the onset of respiratory arrest. Apneic spells, spinal motoneurone inhibition, and cardiac arrhythmias are neurophysiologic processes which tend to occur together and they are facilitated by neurophysiologic mechanisms underlying active sleep.

REM sleep appears to entail the simultaneous occurrence of at least three distinct processes (4):

\section{TONIC MOTOR INHIBITION}

Inhibition at the site of the ultimate central nervous system outlet, ensured by spinal motoneurone hyperpolarization $(21$, 22).

\section{PHASIC ACTIVITY}

Paradoxically, at the same time when spinal motoneurone inhibition prevents almost all central nervous system activity from reaching the musculature, the brain produces enormous bursts of activity which give rise to a series of short lasting events like rapid eye movements, muscular twitchings, sudden changes in pupil diameter, penile erection, and the PGO (pontine-geniculate-occipital) spikes.

\section{CENTRAL NERVOUS SYSTEM AROUSAL}

In many aspects, particularly under the viewpoint of nonspecific measures of central nervous system activity levels like EEG,

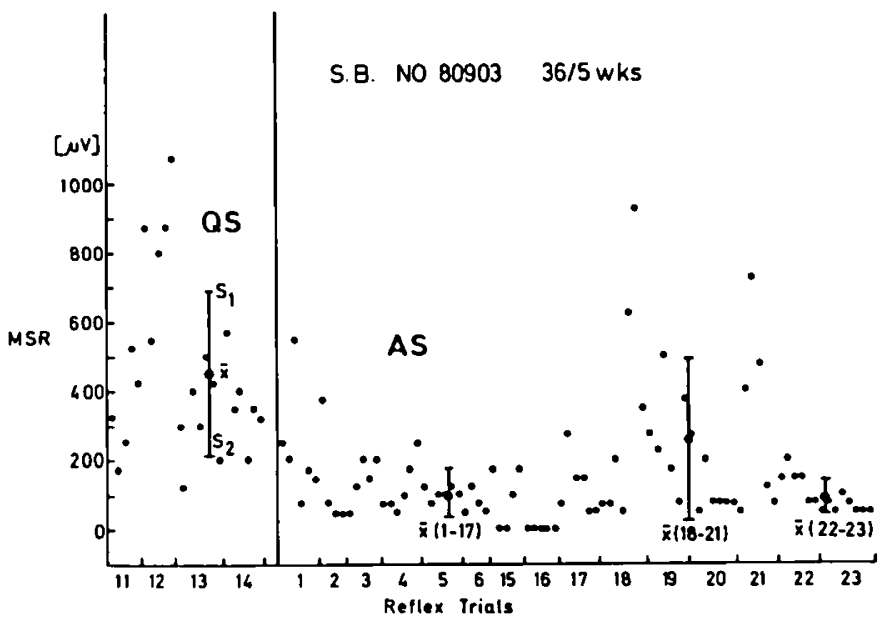

Fig. 4. The amplitude of monosynaptic stretch reflexes (MSR) was invariably depressed during the first part of active sleep. The great variance of MSR during active sleep was mainly because toward the end of the active sleep $(A S)$ state MSR tended to increase. QS: quiet sleep.

Table 3. Sleep states and apnea

\begin{tabular}{lcc}
\hline & \% of time & \% of apnea \\
\hline AS & 61.1 & 77.8 \\
QS & 22.4 & 7.4 \\
UDS & 16.5 & 14.8 \\
\hline
\end{tabular}

1 Apneic spells are rarely observed during quiet sleep (QS). In this study, $78 \%$ of all apnea occurred during active sleep (AS) and only $7 \%$ during quiet sleep, although the percentage of time spent in the two sleep states was $61 \%$ and $22 \%$, respectively. UDS; undifferentiated sleep. Number of recordings $=12$; number of apneic spells $=27$. 


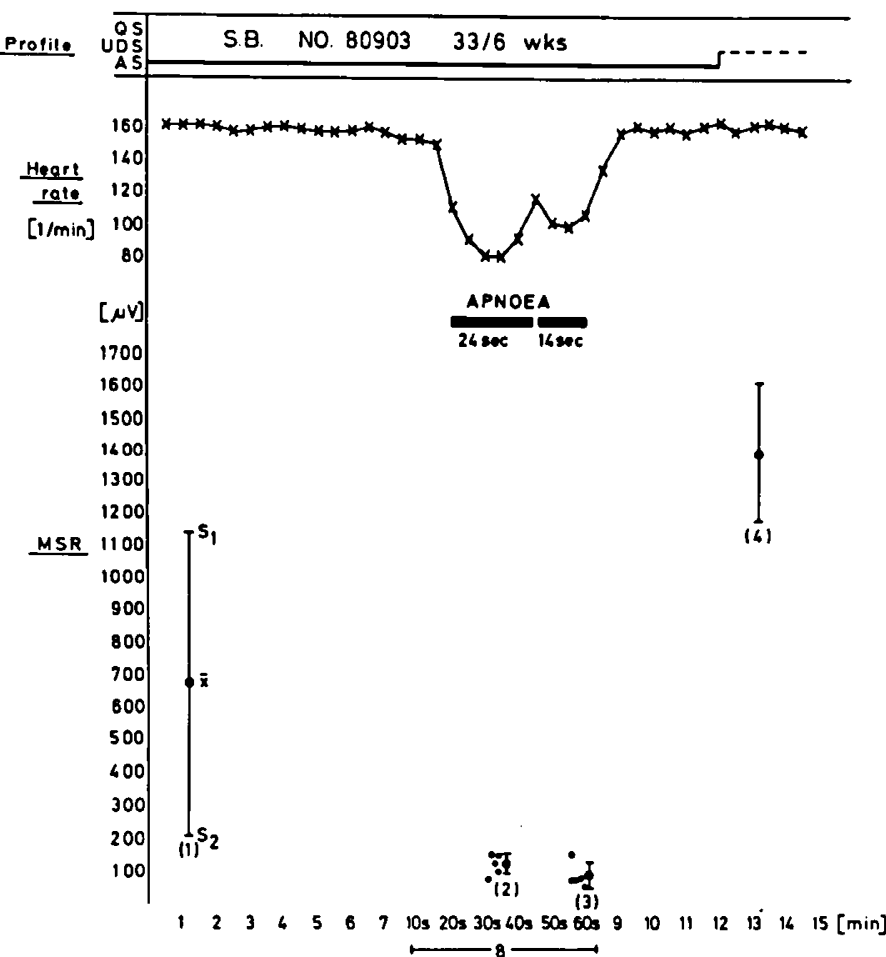

Fig. 5. During an apneic spell monosynaptic reflex responses (MSR) were greatly depressed. QS: quiet sleep; AS: active sleep; UDS: undifferentiated sleep.

brain temperature and cerebral blood flow, the brain in active sleep resembles the awake or arousal state except for the absence of awareness.

It is only with these three active sleep brain mechanisms in mind that we can understand why, during active sleep, the preterm infant breathes faster one minute and stops breathing all together in the next. In the light of the above mentioned REM sleep concept it is also no longer contradictory that the first respiratory movements of the fetus in utero can be detected during active sleep (3). In active sleep there is a continuous competition between strong internal central nervous system arousal and sustained spinal motoneurone inhibition. Tonic inhibition prevents most of the phasic events within the brain from leaving the central nervous system. In preterm infants our study disclosed a remarkable fluctuation of tonic inhibitory processes during active sleep. This explains why, particularly in the very immature infant, a considerable amount of phasic activity escapes from the central nervous system, giving rise to an enormous wealth of twitchings and even to respiratory movements in utero, and why at other times the same baby during active sleep is absolutely flaccid, motionless, and even apneic.

Although less frequent, apneic spells can also occur in quiet sleep. They can probably be explained on the basis of incomplete development of excitatory axodendritic synapses in brain stem respiratory centers as hypothesized by Gabriel et al . (10). Furthermore, a certain number of all apneic spells are undoubtedly due to central nervous dysfunction and/or lung disorders. Such "complicated apnea" was not subject of this study. In this series, when apneic spells occurred during quiet sleep, the amplitude of the gastrocnemius monosynaptic reflex response decreased simultaneously. The inadequate coordination of the different sleep state parameters and their poor maintainance over a longer period of time in immature infants could support the argument that in preterm babies quiet sleep is sometimes interrupted by incomplete bursts of active sleep. Brief and abortive REM sleep episodes may sometimes be indicated either by a change in the ongoing EEG pattern, by a group of eye movements, by a short period of irregular respiration, or sometimes merely by a short spinal motoneurone inhibition including respiratory arrest.

\section{REFERENCES AND NOTES}

1. Baldissera, F., Broggi, G., and Mancia, M.: Monosynaptic and polysynaptic spinal reflexes during physiological sleep and wakefulness. Arch. Ital. Biol., 104: 112 (1966).

2. Bryan, A. C., and Bryan, M. H.: Respiratory control in newborn infant. In: J. W. Dudenhausen, E. Saling, and E. Schmidt: Perinatale Medizin (GeorgThieme Verlag, Stuttgart, 1975).

3. Dawes, G. S., Fox, H. E., Leduc, B. M., Liggins, G. C., and Richards, R. T. Respiratory movements and paradoxical sleep in the foctal lamb. J. Physiol., 210: $47 \mathrm{p}$ (1970).

4. Dement, W. C.: Sleep deprivation and the organization of the behavioral states. In: C. D. Clemente, D. P. Purpura, and F. E. Mayer: Sleep and the Maturing Nervous System (Academic Press, New York, 1972).

5. Dreyfus-Brisac, C.: Sleep ontogenesis in early human prematurity from 24 to 27 weeks of conceptional age. Dev. Psychobiol., 1: 162, (1968).

6. Dreyfus-Brisac, C. Ontogenesis of sleep in human prematures after 32 weeks of conceptional age. Dev. Psychobiol., 3: 91 (1970).

7. Eliet-Flescher, J., and Dreyfus-Brisac, C.: Le sommeil du nouveau-né et du prématuré. Biol. Neonat., 10: 316 (1966).

8. Fenner, A., Schalk, U., Hoenicke, H., Wendenburg, A., and Roehling, T.: Periodic breathing in premature and neonatal babies: Incidence, breathing pattern, respiratory gas tensions, response to changes in the composition of ambient air. Pediat. Res., 7: 174 (1973).

9. Gabriel, M., Albani, M., and Schulte, F. J.: Zentralnervöse Faktoren der Apnoeanfälle Frühgeborener. Klin. Wschr., 53: 934 (1975).

10. Gabriel, M., Albani, M., and Schulte, F. J.: Apnoic spells and sleep states in preterm infants. Pediatrics, 57: 142 (1976).

11. Gabriel, M., and Albani, M.: Cardiac slowing and respiratory arrest in preterm infants. Z. Kinderheilk., 122: 257 (1976).

12. Gassell, M. M., and Pompejano, O.: Fusimotor function during sleep in unrestrained cats. Arch. Ital. Biol., 103: 347 (1965).

13. Giaquinto, S., Pompejano, O., and Somogyi, I.: Descending inhibitory influences on spinal reflexes during natural sleep. Arch. Ital. Biol., 102: 282 (1964).

14. Hodes, R., and Gribetz, I.: H-reflexes in normal human infants: Depression of these electrically induced reflexes (EIRs) in sleep. Proc. Soc. Exp. Biol. N.Y., 110: 577 (1962)

15. Hodes, R., and Dement, W. C.: Depression of electrically induced retlexes (H-reflexes) in man during low voltage EEG sleep. J. EEG Clin. Neurophysiol., 17: 617 (1964).

16. Kubota, K., Imamura, Y., and Nimi, Y.: Monosynaptic reflex and natural sleep in the cat. J. Neurophysiol., 28: 125 (1965).

17. Monod, N., Curzi-Dascalova, L., Guidasci, S., and Valenzuela, S.: Pauses respiratoires et sommeil chez le nouveau-né et le nourrisson. Rev. EEG Neurophysiol., 6: 105 (1976).

18. Parmelee, A. H., Wenner, W. H., Akiyama, Y., Schultz, M., and Stern, E.: Sleep states in premature infants. Develop. Med. Child Neurol., 9: 70 (1967).

19. Parmelee, A. H., Schulte, F. J., Akiyama, Y., Wenner, W. H., Schultz, M. A., and Stern, E.: Maturation of EEG activity during sleep in premature infants. Electroenceph. Clin. Neurophysiol., 24: 309 (1968).

20. Parmelee, A. H., Stern, E., and Harris, M. A.: Maturation of respiration in prematures and young infants. Neuropädiatrie, 3: 294 (1972).

21. Pompejano, O.: Muscular afferents and motor control during sleep. In: $\mathbf{R}$ Granit: Muscular Afferents and Motor Control. Nobel Symposium I, p. 415 (Almquist \& Wiskell, Stockholm, 1966).

22. Pompejano, O.: Sleep Mechanisms. In: H. H. Japser, A. A. Ward, and A. Pope: Basic Mechanisms of Epilepsy, p. 453 (Little, Brown, Boston, 1969).

23. Prechtl, H. F. R., Vlach, V., Lenard, H. G., and Grant, D. K.: Exteroceptive and tendon reflexes in various behavioural states in the newborn infant. Biol. Neonat., 11: 159 (1967).

24. Schulte, F. J., Michaelis, R., Nolte, R., Albert, G., and Lasson, U.: Brain and behavioural maturation in newborn infants of diabetic mothers. Neuropädiatrie, 1: 24 (1969).

25. Steinschneider, A.: Prolonged apnoea and the sudden infant death syndrome: Clinical and laboratory observations. Pediatrics, 50: 646 (1972).

26. We thank Mr. P. Patzig and Mr. H. Wulbrandt for their invaluable assistance in the polygraphic recordings.

27. This research was supported by the Deutsche Forschungsgemeinschaft SFB 33 "Nervensystem und biologische Information."

28. Requests for reprints should be addressed to: F. J. Schulte, M. D., Professor of Pediatrics, Universitäts-Kinderklinik, Humboldtallee 38, 3400 Göttingen, West Germany.

29. Received for publication April 27, 1976.

30. Accepted for publication October 8, 1976. 